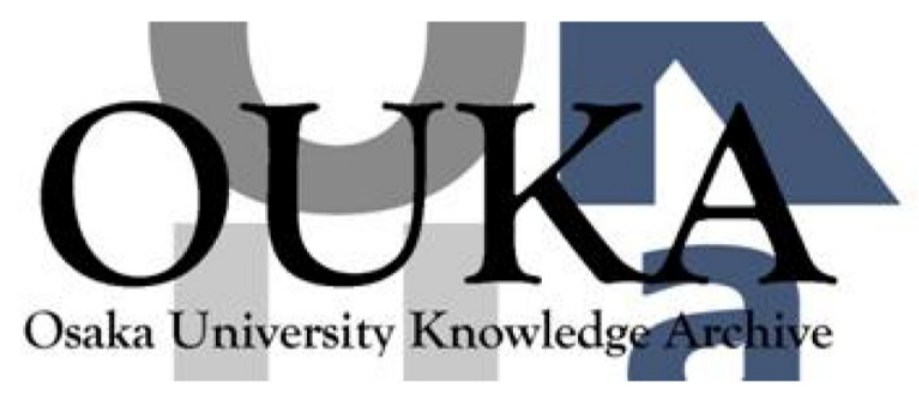

\begin{tabular}{|c|l|}
\hline Title & $\begin{array}{l}\text { Primary structure of human pancreatic } \alpha- \\
\text { amy lase gene }: \text { its comparison with human } \\
\text { salivary } \alpha \text {-amy lase gene }\end{array}$ \\
\hline Author(s) & Hori i, Akira \\
\hline Citation & \\
\hline Issue Date & \\
\hline oaire:version & VoR \\
\hline URL & https://hdl. handle.net/11094/36665 \\
\hline rights & \\
\hline Note & \\
\hline
\end{tabular}

Osaka University Knowledge Archive : OUKA

https://ir. Library. osaka-u. ac. jp/

Osaka University 


\section{Primary structure of human pancreatic $\alpha$-amylase gene: its comparison with human salivary $\alpha$-amylase gene}

(Recombinant DNA; gene conversion; cosmid; evolutionary mouse and human divergence; exon-intron junctions)

\section{Akira Horii, Mitsuru Emi *, Naohiro Tomita, Takahiro Nishide, Michio Ogawa ${ }^{\text {a }}$, Takesada Mori ${ }^{a}$ and Kenichi Matsubara}

Institute for Molecular and Cellular Biology, Osaka University, Yamadaoka, Suita 565 (Japan) and a Second Department of Surgery. Osaka University Medical School, Fukushima-ku, Osaka 553 (Japan) Tel. (06)451-0051

Received 18 June 1987

Revised 11 August 1987

Accepted 18 August 1987

\section{SUMMARY}

We have determined the entire structure of the human pancreatic $\alpha$-amylase (Amy2) gene. It is approx. 9 $\mathrm{kb}$ long and is separated into ten exons. This gene (amy2) has a structure very similar to that of human salivary $\alpha$-amylase (Amy1) gene [Nishide et al. Gene 41 (1986a) 299-304] in the nucleotide sequence and the size and location of the exons. The major difference lies in the fact that amyl has one extra exon on the 5' side. Other differences are at the $5^{\prime}$ border of exon 1 and the $3^{\prime}$ border of exon 10 . The close similarity of these two genes, as compared with mouse pancreatic and salivary amylase genes, suggests that during evolution, the divergence into the two amylase genes may have occurred after the divergence of mice and man.

\section{INTRODUCTION}

Human $\alpha$-amylases which hydrolyze $\alpha$-1,4 glucosidic bonds, consist of two major isozymes, i.e., salivary type and pancreatic type. These two isozymes differ in molecular size (Matsuura et al., 1978; Stiefel et al., 1973), isoelectric point (Matsuura et al.,

Correspondence to: Dr. A. Horii, Institute for Molecular and Cellular Biology, Osaka University, Yamadaoka, Suita 565 (Japan) Tel. (06) 877-5244.

* Present address: Howard Hughes Medical Institute, University of Utah, Salt Lake City, UT 84132 (U.S.A.) Tel. (801) 5813741.
1978) and antigenic propertics (Bochm-Truitt et al., 1978). Our previous studies on cDNAs of salivary and pancreatic $\alpha$-amylases (Nakamura et al., 1984; Nishide et al., 1986b) have shown that at least two different, but closely related genes are transcribed in tissue-specific fashion. In addition, salivary $\alpha$-amylase gene (amyl), but not pancreatic $\alpha$-amylase gene

\footnotetext{
Abbreviations: aa, amino acid(s); Amy 1, human salivary $\alpha$-amylase; amyl, gene, cDNA or mRNA coding for Amyl; Amy2, human pancreatic $\alpha$-amylase; amy2, gene, cDNA or mRNA coding for Amy2; bp, base pair(s); cDNA, DNA complementary to RNA; cos, cosmid; kb, kilobase(s) or $1000 \mathrm{bp}$; N, any nucleoside; nt, nucleotide(s); p, plasmid; PolIk, Klenow (large) fragment of $E$. coli DNA polymerase I.
} 
( $a m y 2$ ), is expressed in some cancers (Y. Nakamura, N.T., T.N., M.E., A.H., M.O., T.M., G. Kosaki, T. Okabe, M. Fujisawa, N. Osawa, T. Kameya and K.M., manuscript in prep.; N.T., N. Matsuura, A.H., M.E., T.N., M.O., T.M., O. Doi, and K.M., $\mathrm{ms}$. in prep.). Thus, it seems to be of interest to clarify the mechanisms of the specific expression control, and therefore, we started to analyze these genes. This paper reports the structure of human amy 2 and compares it with the structure of amyl (Nishide et al., 1986a). The results show that these two genes are remarkably similar, albeit they express differently, suggesting that they separated very recently, or that there has been a very efficient gene conversion process to conserve the sequence during evolution.

\section{MATERIALS AND METHODS}

\section{(a) Enzymes and reagents}

Restriction endonucleases were purchased from Takara Shuzo (Kyoto, Japan) and Toyobo (Osaka Japan). Pollk and Escherichia coli T4 ligase were from Takara Shuzo.

\section{(b) Library screening}

The human genomic cosmid library carrying approx. $40-45-k b$ inserts was kindly provided by Dr. Y. Nakamura (Lau et al., 1983). Recombinant colonies carrying human amyl and amy2 were screened using the mixture of ${ }^{32} \mathrm{P}$-labeled human amyl and amy2 cDNAs (Nishide et al., 1986b) as the probe. Selection of a clone $(\cos \mathrm{P} 2)$ that carries the $a m y 2$ is described in the text.

\section{(c) Mapping of cosmid clones}

Each cosmid clone was digested with some restriction endonucleases, electrophoresed in $0.5 \%$ or $0.35 \%$ agarose gels (Maniatis et al., 1982), transferred and hybridized to ${ }^{32} \mathrm{P}$-labeled $\mathrm{CDNA}$, or to ${ }^{32} \mathrm{P}$-labeled fragment of the cosmid vector DNA, according to Southern (1975). We also used double digestion or partial digestion for fine mapping.

\section{(d) Sequence analysis}

DNA fragments were extracted from the cosmid clone $(\cos \mathrm{P} 2)$, subcloned in pUC8 (Vieira et al., 1982) or in Bluescribe (Vector Cloning Systems), and in M13 vectors mp10, mpl1 (Messing, 1983), mp18 or mp19 (Yanisch-Perron et al., 1985), and sequenced by the dideoxy method (Sanger et al., 1980; Hattori et al., 1986)

\section{(e) $\operatorname{Poly}(A)^{+}$RNA preparation}

A resected human pancreas was frozen in liquid nitrogen and stored at $-70^{\circ} \mathrm{C}$. RNA was isolated as described (Nakamura et al., 1984). Poly(A) ${ }^{+}$RNA was purified by oligo(dT)-cellulose column chromatography.

\section{(f) Primer extension analysis}

Primer extension was carricd out using pancreatic poly $(\mathrm{A})^{+}$RNA as a template and a $5^{\prime}$ end-labeled synthetic oligodeoxynucleotide primer $\left(5^{\prime}-\mathrm{CCAG}\right.$ CAGAACCCAATGGT-3'). This primer is complementary to a sequence of pancreatic $\alpha$-amylase cDNA covering codons 9 through 14. Analysis was carried out in a $6 \%$ polyacrylamide $-8 \mathrm{M}$ urea gel along with appropriate dideoxy sequencing samples as size markers.

\section{RESULTS AND DISCUSSION}

\section{(a) A cosmid carrying the human pancreatic $\alpha$-amy-} lase gene

The human genomic cosmid library was screened with human amyl and amy 2 cDNA probes (Nishide et al., 1986b). Out of $1.2 \times 10^{5}$ colonies screened, nine clones carrying full-length DNA covering an amylase gene were obtained. Eight of them gave an identical restriction cleavage pattern with that of salivary $\alpha$-amylase gene (Nishide et al., 1986a). One, which we named $\cos \mathrm{P} 2$, gave a different cleavage map. As will be shown below, the $\cos \mathrm{P} 2$ carries the DNA that covers the entire human pancreatic $\alpha$ amylase gene. 


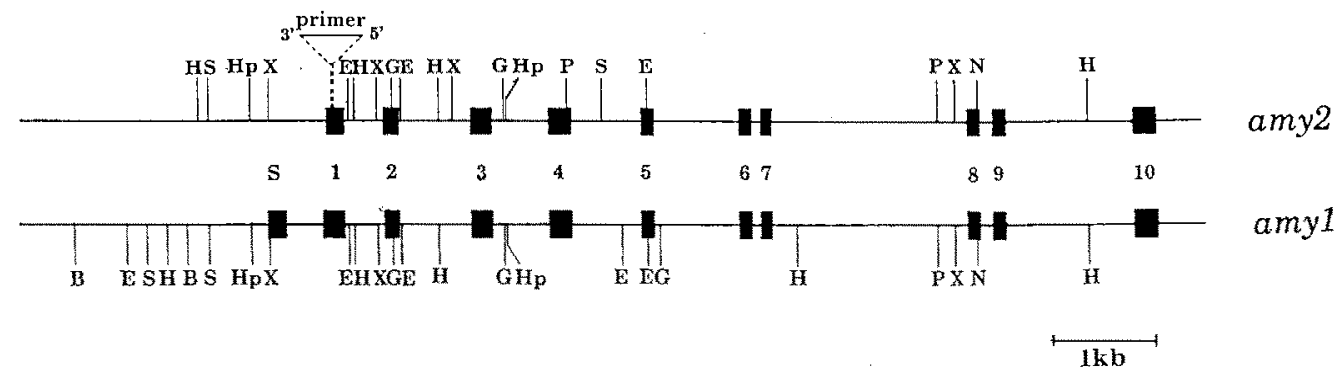

Fig. 1. Restriction map of human genes amy2 and amyl. Relative positions of exons, deduced from the nucleotide sequence, are indicated by solid boxes. B, Bam HI; L, Eco RI; G, BgIII; H, HindIII; Hp, IPaI; N, BanIII; P, PstI; S, SacI; X, XbaI. Only relevant restriction sites are displayed. A few errors in the restriction map previously published (Nishide et al., 1986a) have been corrected. The numbering of the exons in $a m y /$ has been revised so as to unify the nomenclatures for the two genes. The primer used for extension analysis is also shown, with its $5^{\prime}-3^{\prime}$ orientation, above the exon 1 of amy2.

\section{(b) The structure of amy2}

The insert in the $\cos \mathrm{P} 2$ was analyzed by restriction endonucleases. The fragments were monitored by their ability to hybridize to amyl and amy2 cDNA regional probes (Nakamura et al., 1984; Nishide et al., 1986b). The fragments were subcloned for fine restriction mapping and nucleotide sequencing. The restriction map and location of exons (see below) are shown in Fig. 1, and the nucleotide sequence, along with the predicted amino acid sequence, is shown in Fig. 2. The nucleotide sequence of the amino acid coding region, along with its $5^{\prime}$ - and $3^{\prime}$-flanking regions which were regarded to be exons, completely agrees with that of human pancreatic $\alpha$-amylase cDNA (Nishide et al., 1986b). These sequences also agree with the cDNA sequence reported by Wise et al. (1984), except for $1 \mathrm{nt}$ (thymine instead of cytosine) in exon 8 at aa position 370 . These results indicate that the gene we analyzed in $\cos P 2$ is actually the human pancreatic $\alpha$-amylase gene.

Fig. 1 also shows the map and location of exons in amyl. The two genes are very similar in structure including the locations and lengths of exons as well as introns. One of the major differences lies in the fact that amyl has an extra exon, referred to as exon $\mathrm{S}^{*}$, which is lacking from amy2 (see below). The $5^{\prime}$

\footnotetext{
* The exons in amyl were renumbered so as to unify the nomenclature of corresponding exons in the two genes (viz., amy $J$ and amy2). Thus, amy/ consists of exons $\mathrm{S}, 1,2,3, \ldots 9,10$ and $a m y 2$ consists of exons $1,2,3, \ldots 9,10$.
}

border of exon 1 and the $3^{+}$border of exon 10 , each differ to some extent between amy 2 and amyl. The difference in the $5^{\prime}$ border of exon 1 (an extra $32 \mathrm{nt}$ is transcribed in the exon 1 of the amyl) can be used to monitor the presence of a small amount of amy2 mRNA among large amounts of amyl mRNA (Y. Nakamura, N.T., T.N., M.E., A.H., M.O., T.M., G. Kosaki, T. Okabe, M. Fujisawa, N. Osawa, T. Kameya and K.M., ms. in prep.)

In addition to the overall homologies between transcribed sequences in amy2 and amyl, we see striking similarities in the size of introns and the sequences that cover the $5^{\prime}$ and $3^{\prime}$ flanking regions of the two genes. The $5^{\prime}$ untranscribed region of amy2 which corresponds to the exon $\mathrm{S}$ of amyl is $93 \%$ homologous to the exon $\mathrm{S}$. This raised the question as to whether amy2 is transcribed in this region. Accordingly, we determined the transcription start point of amy2 by primer extension analysis, as shown in Fig. 3, using the mRNA from human pancreas. The result showed unambiguously that the transcription starts at 14 bp upstream from the start codon in the exon 1. S1 nuclease mapping confirmed this result (not shown). Therefore, the homologous sequence to the exon $\mathrm{S}$ in amy2 is not transcribed. The TATA box of amy2 lies 29-23 nt upstream from the transcription start point which lies in the exon 1 in amyl. The TATA box of amyl lies farther upstream from the exon S (34-28 nt upstream from the cap site of amyl). 


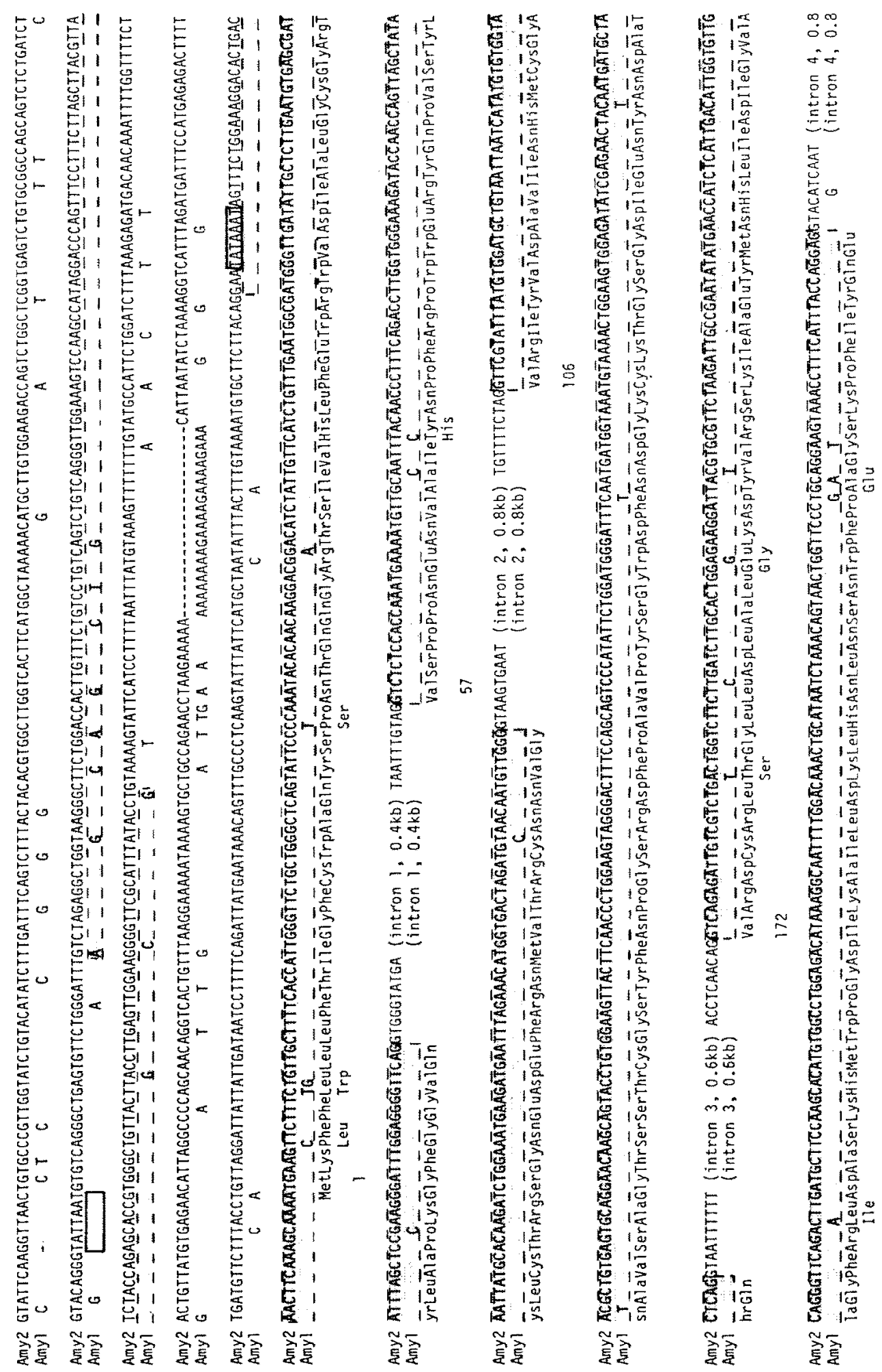




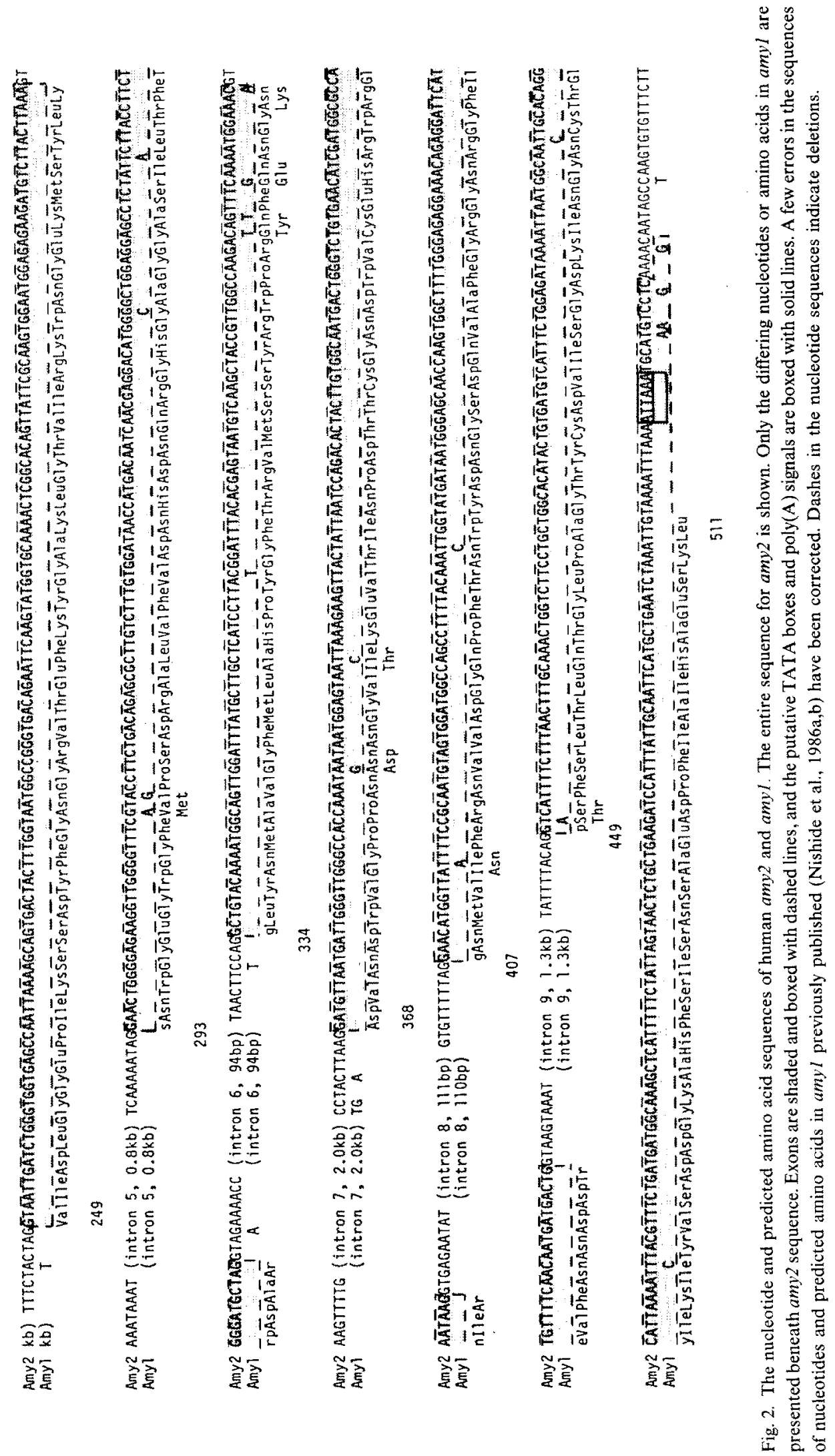




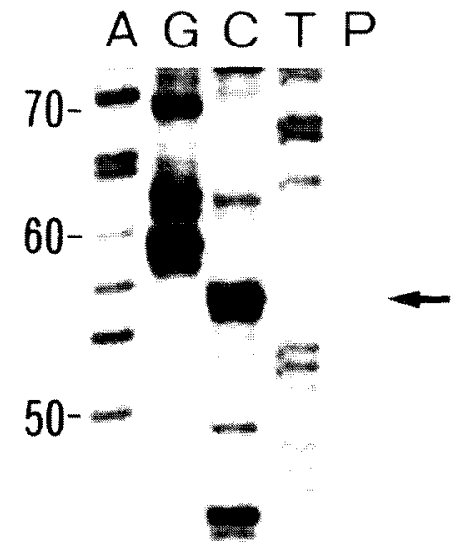

$40^{-}$

Fig. 3. Primer extension analysis. Lanes A, G, C and T show the known nucleotide sequence ladders employed as size standards (30-70 nt). Lane $\mathrm{P}$ shows the cDNA primed with a ${ }^{32} \mathrm{P}-5$ '-endlabeled 18-nt synthetic oligodeoxynucleotide (see MATERIALS AND METHODS, section $\mathbf{f}$, and Fig. 1) using pancreatic poly $(\mathrm{A})^{+}$RNA as a template. The arrow indicates the primer extension product, $56 \mathrm{nt}$ in size, containing a 42 -nt coding region and a 14-nt $5^{\prime}$-nontranslated region.

\section{(c) Comparison of amylase genes between man and mouse}

Schibler et al. (1982) published structures of $\alpha$ amylase genes in mouse. They showed that in this animal the $a m y 2$ gene consists of ten exons and the amyl gene of eleven. In addition to the pancreas and salivary gland, $\alpha$-amylase can be produced in the liver, whose gene consists of eleven exons. The structures of mouse and human $\alpha$-amylase genes are similar from exon 1 through exon 10 , which is equivalent to amy2 (Fig. 4). These four genes show close similarity in sizes of exons 1 through 10 . In this region, the nucleotide sequences of mRNAs representing amy 2 exons are $85 \%$ homologous between man and mice, and $81 \%$ homologous, with respect to amyl exons (Hagenbüchle et al., 1980). Fig. 4 shows that the sizes of introns in human and mouse amylase genes differ to some extent. To our surprise, introns in human pancrcatic and salivary amylasc genes also show very close similarities. As far as we sequenced, the nucleotide sequences are more than $90 \%$ homologous. The extra exon (exon $\mathrm{S}$ ) in the salivary amylase genes in both man and mice have no sequence homology. Moreover, their size and location show no similarities. Thus, the size of exon $\mathrm{S}$ in man is $154 \mathrm{bp}$ and is located $357 \mathrm{bp}$ upstream from the $5^{\prime}$ end of exon 1 , whereas in mice, the size is $50 \mathrm{bp}$ and the location is $7.77 \mathrm{~kb}$ upstream from the $5^{\prime}$ end of exon 1 (Schibler et al., 1982). It thus seems likely that at some stage of evolution, the exon $S$ in both species was created by mutation in the upstream region to the basal ten exons which may represent the primordial amylase gene and is similar to amy2. The expression of amylase in mouse liver (Schibler et al., 1980; 1982; 1983; Young et al., 1981 ) is also mediated through an additional exon, called exon $\mathrm{L}$, that is located at the $5^{\prime}$ side of the basal ten exons. Acquisition of such an extra exon for expression in the salivary gland (or in the liver) in both mammalian species is interesting for the tissue-specific expression of a gene, and suggests that similar mechanisms may be found in some other genes, particularly those coding isozymes that are expressed in tissue-specific fashion.

The nucleotide sequence homology between the basal ten exons in amyl and amy 2 is $98 \%$ in humans. Not only are the lengths and locations of the exons similar, but also the introns and flanking regions. Close similarity between the basal ten exons is also observed in amyl and amy 2 in mice $(89 \%$ homologous). On the other hand, the overall nucleotide sequence homology between corresponding exons from the two mammals is $81 \%$ (salivary type) and $85 \%$ (pancreas type). These data suggest that during evolution, the divergence into the two amylase genes (viz. amyl and amy2) occurred after the divergence of mice and man. Alternatively, the highly conserved sequence homologies within a species, may be accounted for by gene conversion among the members of the amylase gene family.

Swift et al. (1984), Boulet et al. (1986) and Osborn et al. (1987) found a conserved sequence, possibly a part of the enhancer sequence that plays a role in pancreas-specific gene expression. The corresponding $5^{\prime}$ region of human amy2 has the almost identical sequence (AGGTCATTTAGATGATTTCCATGAGAGACTT) at 153-183 bp upstream from the cap site of amy2. Interestingly, the human 


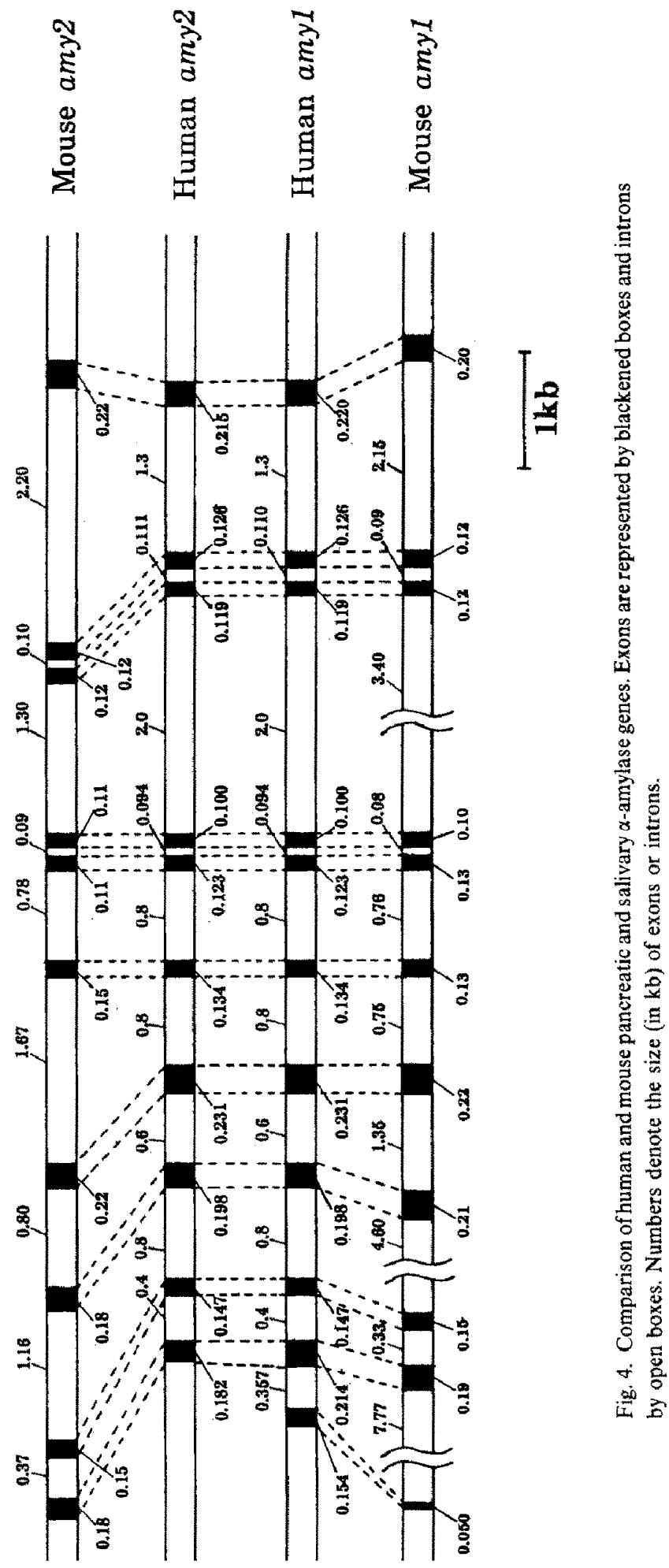


amyl has this sequence, too, except for substitution of 9 th $\mathrm{T}$ by $\mathrm{G}$ in intron $\mathrm{S}$. The 5 '-flanking region of amy 2 is $94 \%$ homologous to the exon $S$ of amyl, as shown in Fig. 2. Our unpublished data show that up to at least $0.6 \mathrm{~kb}$ from the cap site of human amyl, the sequences for amy 1 and amy 2 are very similar. Thus, from sequencing studies alone, it is not possible to point out the cis-acting control regions for tissue-specific expression. Further analyses are needed to clarify these problems.

\section{ACKNOWLEDGEMENTS}

We thank Dr. Y. Nakamura for providing us with the human DNA cosmid library, Drs. T. Yamamoto and $\mathrm{Y}$. Takahashi for their advice and discussions, and Mr. T. Umekage for his technical assistance.

\section{REFERENCES}

Boehm-Truitt, M., Harrison, E., Wolf, R.O. and Notkins, A.L.: Radioimmunoassay for human salivary amylase. Anal. Biochem. 85 (1978) 476-487.

Boulet, A.M., Erwin, C.R. and Rutter, W.J.: Cell-specific enhancers in the rat exocrine pancreas. Proc. Natl. Acad. Sci. USA 83 (1986) 3599-3603.

Hagenbüchle, O, Bovey, R. and Young, R.A.: Tissue-specific expression of mouse $\alpha$-amylase genes: nucleotide sequence of isozyme mRNAs from pancreas and salivary gland. Cell 21 (1980) 179-187.

Hattori, M. and Sakaki, Y.: Dideoxy sequencing method using denatured plasmid templates. Anal. Biochem. 152 (1986) $232-238$.

Lau, Y.-F. and Kan, Y.W.: Versatile cosmid vectors for the isolation, expression, and rescue of gene cluster. Proc. Natl. Acad. Sci. USA 80 (1983) 5225-5229.

Maniatis, T., Fritsch, E.F. and Sambrook, J.: Molecular Cloning. A Laboratory Manual. Cold Spring Harbor Laboratory, Cold Spring Harbor, NY, 1982.

Matsuura, K., Ogawa, M., Kosaki, G., Minamimura, N. and Yamamoto, $T$ :: $\alpha$-Amylase from human pancreatic juice as an electrophoretically pure isozyme. J. Biochem. 83 (1978) $329-332$.

Messing, J.: New M13 vectors for cloning. Methods Enzymol. 101 (1983) 20-78.

Nakamura, Y., Ogawa, M., Nishide, T., Emi, M., Kosaki, G., Himeno, S. and Matsubara, K.: Sequences of cDNAs for human salivary and pancreatic $\alpha$-amylases. Gene 28 (1984) 263-270.

Nishide, T., Nakamura, Y., Emi, M., Yamamoto, T., Ogawa, M., Mori, T. and Matsubara, K.: Primary structure of human salivary $\alpha$-amylase gene. Gene 41 (1986a) 299-304.

Nishide, T., Emi, M., Nakamura, Y, and Matsubara, K: Corrected sequences of $c D N A s$ for human salivary and pancreatic $\alpha$-amylases. Gene 50 (1986b) 371-372.

Osborn, L., Rosenberg, M.P., Keller, S.A. and Meisler, M.H.: Tissue specific and insulin-dependent expression of a pancreatic amylase gene in transgenic mice. Mol. Cell. Biol. 7 (1987) 326-334

Sanger, F., Coulson, A.R., Barrell, B.G., Smith, A.J.H. and Roe, B.A.: Cloning in single-stranded bacteriophage as an aid to rapid DNA sequencing. J. Mol. Biol. 143 (1980) 161-178.

Schibler, U., Tosi, M., Pittet, A.-C., Fabiani, L. and Wellauer, P.K.: Tissue-specific expression of mouse $\alpha$-amylase genes. J. Mol. Biol. 142 (1980) 93-116.

Schibler, U., Pittet, A.-C., Young, R.A., Hagenbüchle, O., Tosi, M., Gellman, S. and Wellauer, P.K.: The mouse $x$-amylase multigene family: Sequence organization of members expressed in the pancreas, salivary gland and liver. J. Mol. Biol. 155 (1982) 247-266.

Schibler, U., Hagenbüchle, O., Wellauer, P.K. and Pittet, A.C.: Two promoters of different strengths control the transcription of the mouse alpha-amylase gene $A m y-l^{\text {a }}$ in the parotid gland and the liver. Cell 33 (1983) 501-508.

Southern, E.M.: Detection of specific sequences among DNA fragments separated by gel electrophoresis. J. Mol. Biol. 98 (1975) $503-517$.

Stiefel, D.J. and Keller, P.J.: Preparation and some properties of human pancreatic amylase including a comparison with human parotid amylase. Biochim. Biophys. Acta 302 (1973) $345-361$.

Swift, G.H., Craik, C.S., Stary, S.J., Quinto, C., Lahaie, R.G., Rutter, W.J. and MacDonald, R.J.: Structure of the two related elastase genes expressed in the rat pancreas. J. Biol. Chem. 259 (1984) 14271-14278.

Vieira, J, and Messing, J.: The pUC plasmids, an M13mp7-derived system for insertion mutagenesis and sequencing with synthetic universal primers. Gene 19 (1982) 259-268

Wise, R.J., Karn, R.C., Larsen, S.H., Hodes, M.E., Gardell, S.J. and Rutter, W.J.: A complementary DNA sequence that predicts a human pancreatic amylase primary structure consistent with the electrophoretic mobility of the common isozymes, Amy2 A. Mol. Biol. Med. 2 (1984) 307-322.

Yanisch-Perron, C., Vieira, J. and Messing, J.: Improved M13 phage cloning vectors and host strains: nucleotide sequence of the M13mp18 and pUC19 vectors. Gene 33 (1985) 103-119.

Young, R.A., Hagenbüchle, O. and Schibler, U.: A single mouse $\alpha$-amylase gene specifies two different tissue-specific mRNAs. Cell 23 (1981) 451-458.

Communicated by H. Yoshikawa. 